\title{
Differentiation and roles of bone marrow-derived cells on the tumor microenvironment of oral squamous cell carcinoma
}

\author{
CHANG ANQI $^{1,2^{*}}$, KIYOFUMI TAKABATAKE ${ }^{1 *}$, HOTAKA KAWAI $^{1}$, MAY WATHONE OO $^{1}$, \\ SAORI YOSHIDA ${ }^{1}$, MASAE FUJII ${ }^{1}$, HARUKA OMORI ${ }^{1}$, SHINTARO SUKEGAWA ${ }^{1,3}$, \\ KEISUKE NAKANO $^{1}$, HIDETSUGU TSUJIGIWA ${ }^{1,4}$, ZHENG JINHUA $^{2}$ and HITOSHI NAGATSUKA ${ }^{1}$ \\ ${ }^{1}$ Department of Oral Pathology and Medicine, Graduate School of Medicine, Dentistry and Pharmaceutical Sciences, \\ Okayama University, Okayama 700-8525, Japan; ${ }^{2}$ Department of Anatomy, Basic Medical Science College, \\ Harbin Medical University, Harbin, Heilongjiang 150081, P.R. China; ${ }^{3}$ Department of Oral and Maxillofacial Surgery, \\ Kagawa Prefectural Central Hospital, Kagawa 760-8557; ${ }^{4}$ Department of Life Science, Faculty of Science, \\ Okayama University of Science, Okayama 700-0005, Japan
}

Received May 23, 2019; Accepted September 6, 2019

DOI: $10.3892 / \mathrm{ol} .2019 .11045$

\begin{abstract}
The stroma affects the properties and dynamics of the tumor. Previous studies have demonstrated that bone marrow-derived cells (BMDCs) possess the capability of differentiating into stromal cells. However, the characteristics and roles of BMDCs in oral squamous cell carcinoma remain unclear. The current study therefore investigated their locations and features by tracing green fluorescent protein (GFP)-labeled BMDCs in a transplantation mouse model. After irradiation, BALB-c nu-nu mice were injected with bone marrow cells from C57BL/6-BALB-C-nu/nu-GFP transgenic mice. These recipient mice were then injected subcutaneously in the head with human squamous cell carcinoma-2 cells. Immunohistochemistry for GFP, Vimentin, CD11b, CD31 and $\alpha$-smooth muscle actin
\end{abstract}

Correspondence to: Dr Kiyofumi Takabatake or Professor Hitoshi Nagatsuka, Department of Oral Pathology and Medicine, Graduate School of Medicine, Dentistry and Pharmaceutical Sciences, Okyama University, 2-5-1 Shikata-cho, Kita-ku, Okayama 700-8525, Japan

E-mail: gmd422094@s.okayama-u.ac.jp

E-mail: jin@okayama-u.ac.jp

*Contributed equally

Abbreviations: $\alpha$-SMA, alpha smooth muscle actin; BMDCs, bone marrow-derived cells; BMT, bone marrow transplantation; CAFs, cancer-associated fibroblasts; GFP, green fluorescent protein; HSC-2 cells, human squamous cell carcinoma-2 cells; $\mathrm{H} \& \mathrm{E}$, hematoxylin-eosin; IHC, immunohistochemistry; OSCC, oral squamous cell carcinoma; TAMs, tumor-associated macrophages; TME, tumor microenvironment

Key words: bone marrow-derived cells, oral cancer, cancer stroma, green fluorescence protein transplanted mouse, tumor microenvironment
(SMA), and double-fluorescent immunohistochemistry for GFP-Vimentin, GFP-CD11b, GFP-CD31 and GFP- $\alpha$-SMA was subsequently performed. Many round-shaped GFP-positive cells were observed in the cancer stroma, which indicated that BMDCs served a predominant role in tumorigenesis. Vimentin $(+) \mathrm{GFP}(+)$ cells may also be a member of the cancer-associated stroma, originating from bone marrow. Round or spindle-shaped CD11b(+) $\mathrm{GFP}(+)$ cells identified in the present study may be macrophages derived from bone marrow. CD31(+) GFP(+) cells exhibited a high tendency towards bone marrow-derived angioblasts. The results also indicated that spindle-shaped $\alpha-\operatorname{SMA}(+) \mathrm{GFP}(+)$ cells were not likely to represent bone marrow-derived cancer-associated fibroblasts. BMDCs gathering within the tumor microenvironment exhibited multilineage potency and participated in several important processes, such as tumorigenesis, tumor invasion and angiogenesis.

\section{Introduction}

Solid tumors are composed of parenchyma and stroma, which participate informing cancer-stroma interactions that favor tumor invasive growth in the tumor microenvironment (TME) (1). Recently, some studies have focused on the cellular composition of the TME and suggested that the interactions between cancer cells and stroma may be crucial for progression of various types of carcinomas (2-5). Cancer progression is recognized as the product of evolving crosstalk between cancer cells and various stromal constituents, including the extracellular matrix (6) and fibroblasts. These stromal fibroblasts, which compose the major stromal compartment (7), are often termed myofibroblasts or cancer-associated fibroblasts (CAFs). These cells play an extremely central role in the sophisticated process of tumor-stroma interactions and subsequent carcinogenesis (8-12). Many researchers have already identified the 'reactive stroma' as an inducer that helps to create a growth-promoting TME, which is accompanied by modified extracellular matrix components (13), elevated angiogenesis $(14,15)$, modified fibroblasts (CAFs), etc. In the microenvironment of cancers including those 
in the oral and maxillofacial regions, CAFs play a primary role in cancer development and progression at all stages (16-18). The overall effects of CAFs and altered extracellular matrix in cancers are still poorly understood. Additionally, tumor-associated macrophages (TAMs), the specific type of macrophages present in cancer stroma, are involved in tumor growth and metastasis. These stromal-specific fibroblasts and macrophages acquire abnormalities by interacting with cancer cells, along with gene expression and various biological properties in normal tissues (13). Tumor blood vessels also exist in TME and nourish not only cancer cells but also stromal cells. In this way, the cancer-associated stroma promotes cancer development and progression in many ways.

Cancer-stroma interactions depend on the organs in which the cancer develops, and the whole picture is now being revealed in several types of cancer (19). However, few articles have focused on cancer-stroma interactions in oral squamous cell carcinoma (OSCC), and the cellular composition of the stroma in OSCC has not been fully elucidated in detail.

Recent studies have reported that bone marrow-derived cells (BMDCs) act as not only a source of cells for tissue regeneration $(20,21)$ but also as participants in tumor invasion and proliferation (22). In normal tissue, BMDCs differentiate into various kinds of cells $(23,24)$ in normal head and neck sites such as intestinal mucosal epithelium and salivary glands $(25,26)$. Furthermore, BMDCs are thought to be recruited from bone marrow adjacent to injured tissue during wound healing and cancer progression. In tumors, circulating BMDCs possess the capability of differentiating into vascular endothelial cells, myofibroblasts, etc., (27-29). Thus, BMDCs can differentiate into various cell types that constitute the stroma of the tumor. As described above, BMDCs are closely involved in tumorigenesis as well as cancer progression.

Although the multilineage differentiating ability of BMDCs has already been explored, the distribution, characteristics, and precise roles of BMDCs in tumorigenesis and cancer invasion of OSCC remain unclear. Thus, in this study, we investigated the locations and characteristics of stromal cells and how BMDCs affect cancer development and invasion of OSCC. We used a mouse bone marrow transplantation (BMT) model that was created by grafting bone marrow cells from green fluorescent protein (GFP) mice into BALB-c nu-nu mice. This GFP-transplanted mouse model allows tracking of BMDCs via tracing of GFP-positive cells. Then, these recipient mice were transplanted with a human oral cancer cell line (HSC-2 cells) injected into their head.

\section{Materials and methods}

Mouse strains and cell lines. All animal experiments were performed in accordance with relevant guidelines and regulations and were approved by the institutional committees at Okayama University (OKU-2017406). A total of sixteen female mice (4 C57BL/6-BALB-C-nu/nu-GFP transgenic mice and 12 BALB-c nu-nu mice) were used. The HSC-2 human oral squamous cell carcinoma cell line was purchased from JRCB Cell Bank and cultured in Dulbecco's modified Eagle's medium (DMEM) (Invitrogen) with $10 \%$ fetal bovine serum (FBS) and $100 \mathrm{U} / \mathrm{ml}$ antimycotic-antibiotic at $37^{\circ} \mathrm{C}$ in a humidified atmosphere with $5 \% \mathrm{CO}_{2}$.
BMT model. BMT was carried out according to a standard protocol as described previously (30). Bone marrow cells from GFP mice were collected by introducing DMEM (Invitrogen) into the marrow space. Cells were resuspended in Hanks' Balanced Salt Solution (Invitrogen) in a volume of approximately $1.0 \times 10^{7}$ cells $/ 0.20 \mathrm{ml}$. Subsequently, 8 -week-old female nude recipient mice underwent $10 \mathrm{~Gy}$ of lethal whole-body irradiation, and resuspended bone marrow cells were injected into the tail vein of recipient mice. The bone marrow in the tibial epiphysis was examined with GFP immunohistochemistry (IHC) 4 weeks after transplantation.

Head lesion tumor mouse model. In this study, we used oral squamous cell carcinoma cell line: HSC-2, because we have already known that HSC-2 induced abundant stroma in previous study (31). Four weeks after BMT, 12-week-old BALB-c nu-nu female mice that underwent GFP BMT were injected subcutaneously into the head with $1.0 \times 10^{6} \mathrm{HSC}-2$ cells. In implantation of HSC-2, mice were anesthetized intraperitoneally with ketamine hydrochloride $(75 \mathrm{mg} / \mathrm{kg}$ body weight), medetomidine hydrochloride $(0.5 \mathrm{mg} / \mathrm{kg}$ body weight $)$ and we confirmed whether mice were anesthetize atipamezole hydrochloride (1 $\mathrm{mg} / \mathrm{kg}$ body weight) was injected subcutaneously when awakening. This anesthesia protocol has been improved with reference to Laboratory Animal Anaesthesia, 3rd edition, and were approved by the institutional committees at Okayama University (OKU-2017406). We confirmed mice anesthesia whether mice could return to lying face down when mice were laid supine position. Since this cancer cells injection in head lesion did not impacted negatively in the wellbeing of the all mice, twenty-eight days later, all mice were sacrificed by isoflurane excess inhalation anesthesia (concentration more than 5\%). Then we verified cardiac arrest by palpation and dislocated the cervical spine of the mice according to AVMA Guideline for Euthanasia of Animal 2013 Edition. And the specimens were harvested for analysis. We established humane endpoints such as eating and drinking problems, symptoms of distress (self-harm, abnormal posture, respiratory problems), long-term appearance abnormalities without signs of recovery (diarrhea, bleeding, dirt on vulva), rapid weight loss (more than $20 \%$ in several days), and the cancer tissue size to $3 \mathrm{~cm}$ or more. The experiment was discontinued if the mice's pain was judged to be intolerable and the mice were euthanized.

Histological examination. All embedded tissues were fixed in $4 \%$ paraformaldehyde for $12 \mathrm{~h}$ and then decalcified in $10 \%$ EDTA for 3 weeks. Tissues were processed and embedded in paraffin wax via routine histological preparation and sectioned at $5-\mu \mathrm{m}$ thickness. The sections were used for hematoxylin-eosin (H\&E) staining, IHC, and double-fluorescent IHC.

Immunohistochemistry. IHC was carried out using the antibodies detailed in Table I. Following antigen retrieval, sections were treated with $10 \%$ normal serum for $30 \mathrm{~min}$, and then incubated with primary antibodies at $4^{\circ} \mathrm{C}$ overnight. The immunoreactive site was identified via the avidin-biotin complex method (Vector Lab).

Double-fluorescent IHC staining. Double-fluorescent IHC for GFP-CD11b, GFP-CD31, GFP-Vimentin, and GFP-Alpha 
Table I. Antibodies used in immunohistochemistry.

Supplier

\begin{tabular}{|c|c|c|c|c|}
\hline Primary antibody & Immunized animal & Antigen retrival & Dilution & (catalogue no.) \\
\hline \multirow[t]{2}{*}{ GFP } & Rabbit & $0.1 \%$ trysin at $37^{\circ} \mathrm{C}, 5 \mathrm{~min}$ & $1: 1,000$ & $\begin{array}{l}\text { MBL } \\
(598)\end{array}$ \\
\hline & Goat & Heated in $0.01 \mathrm{~mol} / 1$ citrate buffer for $1 \mathrm{~min}$ & 1:200 & $\begin{array}{c}\text { Abcam } \\
\text { (ab6673) }\end{array}$ \\
\hline CD11b & Rabbit & Heated in $0.01 \mathrm{~mol} / 1$ citrate buffer for $1 \mathrm{~min}$ & $1: 1,000$ & $\begin{array}{c}\text { Abcam } \\
(\mathrm{ab} 133357)\end{array}$ \\
\hline CD31 & Rat & $0.1 \%$ trysin at $37^{\circ} \mathrm{C}, 5 \mathrm{~min}$ & $1: 500$ & $\begin{array}{c}\text { Abcam } \\
\text { (ab56299) }\end{array}$ \\
\hline Vimentin & Rabbit & Heated in $0.01 \mathrm{~mol} / 1$ citrate buffer for $1 \mathrm{~min}$ & $1: 100$ & $\begin{array}{c}\text { Abcam } \\
\text { (ab16700) }\end{array}$ \\
\hline$\alpha$-SMA & Rabbit & Heated in $0.01 \mathrm{~mol} / 1$ citrate buffer for $1 \mathrm{~min}$ & $1: 100$ & Abcam (ab5694) \\
\hline
\end{tabular}

GFP, green fluorescent protein; $\alpha$-SMA, alpha smooth muscle actin; MBL, Medical and Biological Laboratories Co., Ltd.

smooth muscle actin ( $\alpha$-SMA) was performed using GFP monoclonal antibodies (Abcam). The secondary antibodies applied are detailed in Table II. Antibodies were diluted with Can Get SignalA (TOYOBO). After antigen retrieval, sections were treated with Block Ace (DS Pharma Bio-medical) for $30 \mathrm{~min}$ at room temperature. Specimens were incubated with primary antibodies at $4{ }^{\circ} \mathrm{C}$ overnight and then incubated with secondary antibodies (1:200) for $1 \mathrm{~h}$ at room temperature. After the reaction, the specimens were stained with $1 \mathrm{mg} / \mathrm{ml}$ DAPI (Dojindo Laboratories).

Cell counting. Cell counting was performed in three areas (Fig. 1A): The skin side (Fig. 1B), the center part of the tumor (Fig. 1C), and the bone side (Fig. 1D). The subsequent histological analysis as well as findings of their characteristics were made according to these divisions. In each areas, cells were counted in five randomly chosen fields from selected regions (magnification, x200). Then, three members in our group manually and counted the numbers of GFP(+) cells as well as double-positive cells using Image $\mathrm{J} 1.47 \mathrm{v}$ [developed by Wayne Rasband, the National Institute of Health (NHS)]. In each areas, we measured the $\operatorname{GFP}(+)$ cells in cancer stroma and we calculated the ratio of $\mathrm{GFP}(+)$ cells in cancer stroma to determine the average of the 3 areas. The obtained average value was compared in each group, the rate of GFP(+) cells were compared in 3 areas.

Statistical analysis. All values are the mean \pm standard deviation. Statistical analysis was performed using one-way ANOVA and Tukey's tests. $\mathrm{P}<0.05$ was considered to indicate a statistically significant difference. All calculations were made using PASW Statistics 18 (SPSS Inc.).

\section{Results}

Histopathological characteristics of the OSCC-transplanted mouse model. On twenty-eight day, the cancer cells were successful engraftment and the largest tumor mass diameter was
$15 \mathrm{~mm}$ and multiple tumors and metastasis were not observed in our study. From H\&E staining results, HSC-2 cancer cells grew with the stroma around and in the center of cancer tissues. In the center part of cancer tissues, keratinization, which is a typical finding of well-differentiated squamous cell carcinoma, was observed (Fig. 1A). The cancer tissues were composed of loosely arranged spindle-shaped or round-shaped, relatively small cancer cells, which made contact with stromal cells on the skin side (Fig. 1B). Similarly, cancer cells were round or polygonal in shape in the center area. However, cancer cells along the periphery of the cancer stroma appeared to be polymorphic in shape, bigger, and had a darker nucleus and tighter connections (Fig. 1C). Interestingly, cancer cells seemed to be distributed around the front layers, and the most atypical cells were in the bone side of the tumor (Fig. 1D).

GFP-positive cell location and cell shape. Abundant GFP-positive cells infiltrated the TME of the three areas. The majority of them were located along the peripheral sides of the cancer parenchyma and seemed to parallel the tumor in the skin side (Fig. 1E) and bone side (Fig. 1G), which may represent the front layers. On the other hand, in the central part of the cancer tissue, GFP-positive cells were not parallel to the cancer nest, but accumulated in the central part of the cancer stroma (Fig. 1F). GFP-positive cells were round or spindle-shaped in the skin side (Fig. 1E), whereas they appeared rounder and larger in the center side (Fig. 1F). Intriguingly, they were thinner and smaller in the bone side (Fig. 1G).

GFP-positive cell counting analysis. The number of GFP-positive cells in the three areas was counted (Fig. 1H). The number of GFP-positive cells in the center side was significantly higher than in the other two sides $(\mathrm{P}<0.05)$.

Vimentin location and cell shape. The cancer stroma consists of mesenchymal cells, and thus, we performed staining for Vimentin, which is a popular marker of these cells. Almost all stromal cells were Vimentin positive in the three areas. 
Table II. Antibodies used in double-fluorescent immunohistochemistry.

\begin{tabular}{|c|c|c|c|}
\hline Secondary antibody & Immunized animal & Fluorescent dye & Supplier (catalogue no.) \\
\hline \multirow[t]{2}{*}{ Anti Goat IgG } & Donkey & Alexa Flour 568 & $\begin{array}{l}\text { Thermo } \\
\text { (A11057) }\end{array}$ \\
\hline & Donkey & Alexa Flour 488 & $\begin{array}{l}\text { Thermo } \\
\text { (A11055) }\end{array}$ \\
\hline Anti Rat IgG & Donkey & Alexa Flour 488 & $\begin{array}{l}\text { Thermo } \\
\text { (A21209) }\end{array}$ \\
\hline \multirow[t]{2}{*}{ Anti Rabbit IgG } & Donkey & Alexa Flour 568 & $\begin{array}{l}\text { Thermo } \\
\text { (A10042) }\end{array}$ \\
\hline & Donkey & Alexa Flour 488 & $\begin{array}{l}\text { Thermo } \\
\text { (A21441) }\end{array}$ \\
\hline
\end{tabular}

Thermo, Thermo Fisher Scientific, Inc.

In the skin side, the GFP-positive cells were spindle- and round-shaped, and were distributed in the front layers (Fig. 2A). On the other hand, spindle-shaped cells were seen along the peripheral edges of cancer nests in the center side, and these cells were obviously larger in size (Fig. 2B). In the bone side, most of the positive cells were spherical or dendritic, and were the smallest in the three areas. These cells morphologically resembled GFP-positive cells (Fig. 2C).

Vimentin double-fluorescent staining. Spherical or dendritic-shaped Vimentin(+)GFP(+) cells were observed in the skin side (Fig. 2D), center side (Fig. 2E), and bone side (Fig. 2F).

Vimentin cell counting analysis. No significant differences were found among the three regions. However, Vimentin-positive cells tended to increase in the following order: Skin side, center side, bone side (Fig. 2G, left). Interestingly, the percent of dual-positive cells in the bone side, which represents the front layers of the bone invasion area, was significantly the highest among the three areas of cancer $(\mathrm{P}<0.05$; Fig. $2 \mathrm{G}$, right). Also, the average percent among the three areas was calculated as $27 \%$ (data shown in Fig. 2G, right).

CD11b location and cell shape. CD11b is a marker of various kinds of monocytes, especially macrophages, some of which are TAMs in tumors. Numerous studies have reported that CD11b plays a role in invasion as well as metastasis of cancer. Abundant CD11b-positive cells infiltrated stromal tissues in the three areas. CD11b-positive cells were spindle-shaped, located in parallel with each other, and scattered along the front layers in the skin side (Fig. 3A) and bone side (Fig. 3C). Many spherical or dendritic-shaped CD11b-positive cells were found in the stroma of the center side (Fig. 3B), and were similar to GFP-positive cells in shape. Moreover, CD11b-positive cells were also observed around necrotic areas of the cancer center (Fig. 3B; x100, black arrows).

CD11b double-fluorescent staining. Spindle-shaped GFP-positive cells co-expressing CD11b were observed along the front layers mostly in the skin side (Fig. 3D) and bone side
(Fig. 3F). These cells had critical impacts on cancer invasion. At the same time, these double-positive, round or dendritic cells infiltrated necrotic areas of the cancer center (Fig. 3E).

CD11b cell counting analysis. The accumulation of CD11b-positive cells tended to be higher in the central area, although no significant difference was observed (Fig. 3G, left). On the other hand, the percent of CD11b(+)GFP(+) cells in the bone side, which represented the front layers of the bone invasion area, was the highest among the three areas of cancer, although the difference was not significant (Fig. 3G, right).

CD31 location and cell shape. CD31 is a marker associated with angiogenesis and labels vascular endothelial cells of blood vessels in cancer tissues. Our findings were consistent with other experiments showing that CD31 was positive in vascular endothelial cells that formed lumens. The majority of the vessels in the skin side (Fig. 4A) and bone side (Fig. 4C) had smaller and narrower cavities. On the other hand, mature blood vessels with larger lumens and thicker walls were found in the center side of the tumor (Fig. 4B). In addition, spherical or dendritic cells with no evidence of lumen formation were CD31 positive. These spherical or dendritic CD31-positive cells were located adjacent to the cancer invasive front both in the skin side (Fig. 4A) and bone side (Fig. 4C).

CD31 double-fluorescent staining. In the skin side (Fig. 4D) and bone side (Fig. 4F), abundant spherical double-positive cells were found to a higher extent than in the center side (Fig. 4E).

CD31 cell counting analysis. The number of CD31-positive cells tended to be lower in the peripheral sides such as the skin side and bone side than in the central area of the cancer (Fig. 4G, left). However, the number of CD31(+)GFP(+) cells tended to be higher in peripheral sides than in the central area of the cancer (Fig. 4G, right).

$\alpha$-SMA location and cell shape. $\alpha$-SMA is considered to be a common marker of myoepithelial cells, especially CAFs, in many cancer types (32). Many $\alpha$-SMA-positive cells were detected in the three areas of the cancer. These cells were 
A

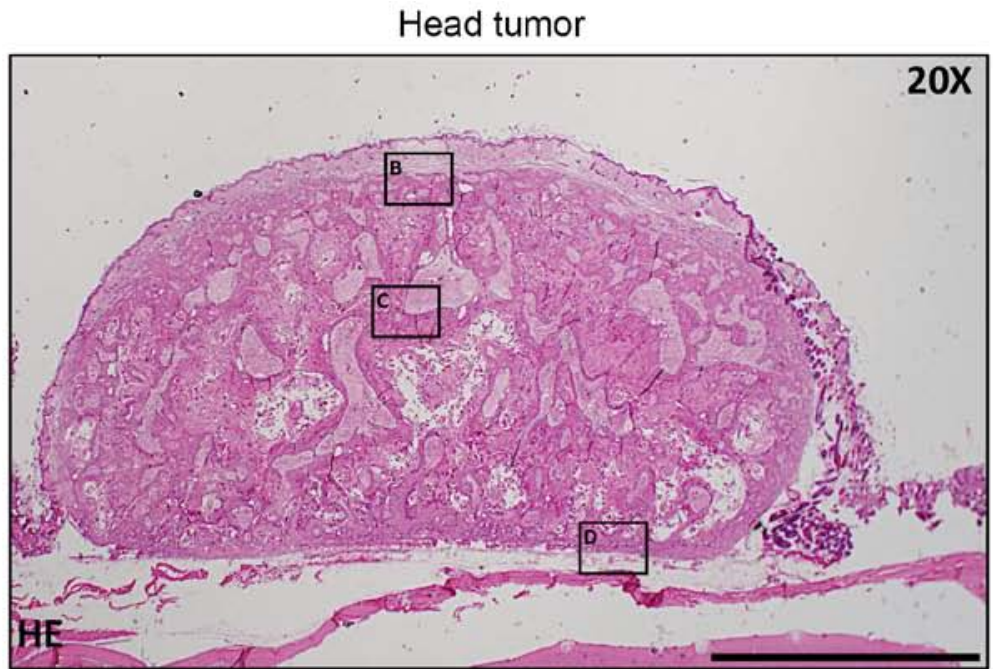

B

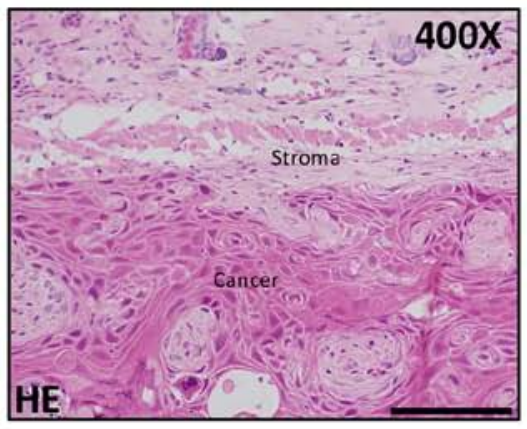

E

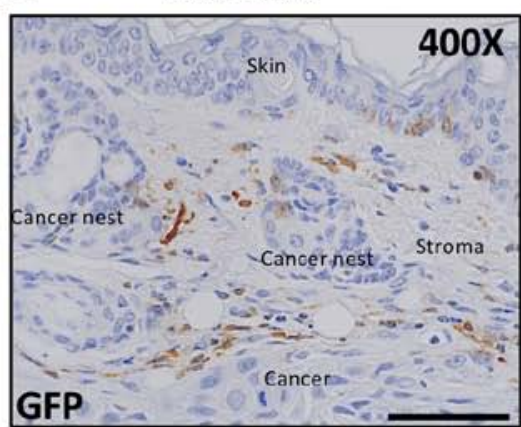

C

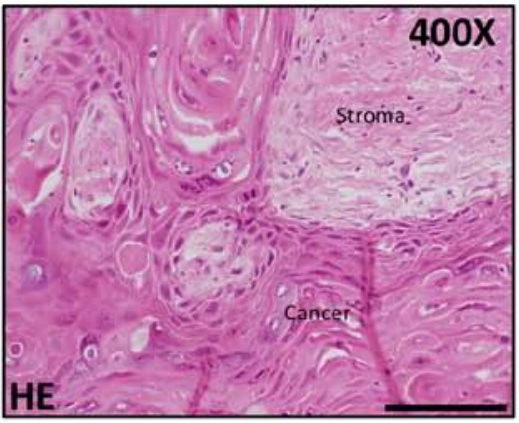

$\mathrm{F}$

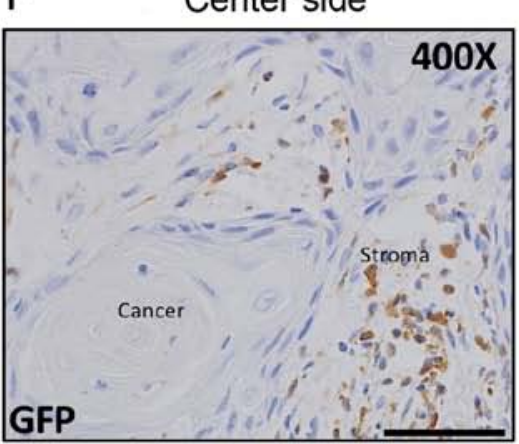

D

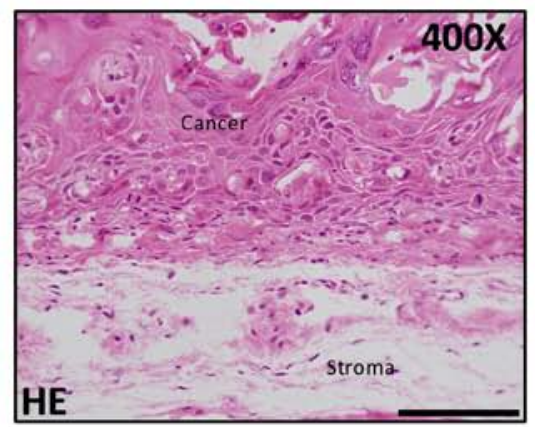

G

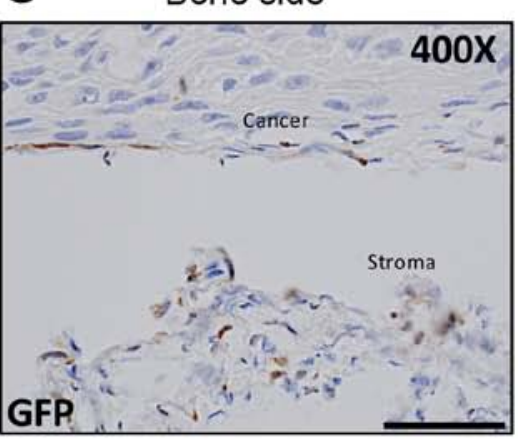

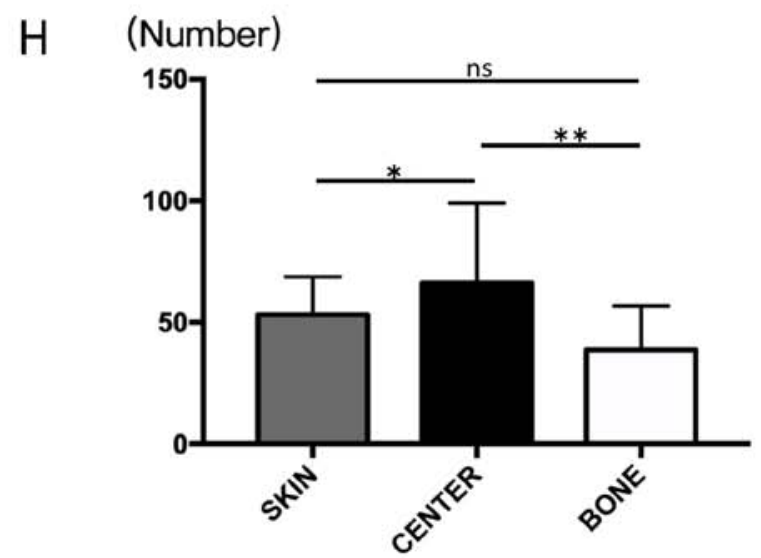

Figure 1. Histopathological appearances and IHC for GFP. Hematoxylin-eosin staining was performed. (A) Loupe image of head cancer tissue (Scale bar, $2 \mathrm{~mm}$; magnification, x20). Round or spindle-shaped cancer cells were observed in (B) the skin side, (C) the center side and (D) the bone side of the tumor. Scale bars in (B-D), $100 \mu \mathrm{m}$ (magnification, $\mathrm{x} 400$ ). GFP IHC staining was subsequently performed. GFP-positive cells were mononuclear cells and round or dendritic cells, and were demonstrated on the (E) skin side, (F) center side and (G) bone side of the tumor. Scale bars in (E-G), 1,500 $\mu \mathrm{m}$ (magnification, $\mathrm{x} 400$ ). (H) The number of GFP-positive cells was significantly higher in the center side of the tumor compared with the skin and bone side. ${ }^{*} \mathrm{P}<0.01$ and ${ }^{* * *} \mathrm{P}<0.001$ as indicated. IHC, immunohistochemistry; GFP, green fluorescence protein; ns, no significance. 
A

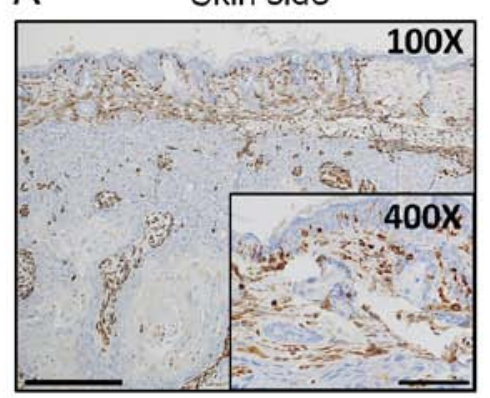

D
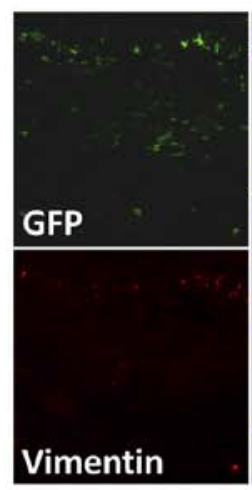

F

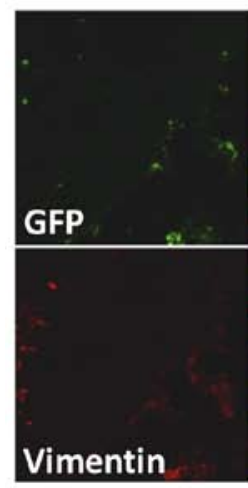

B

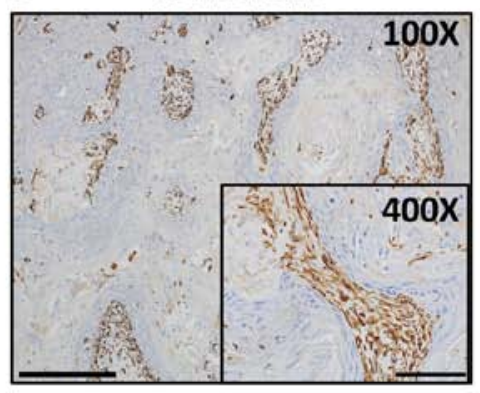

E

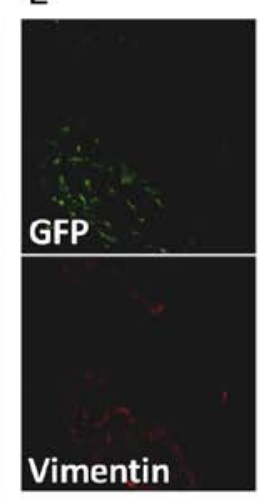

C Bone side

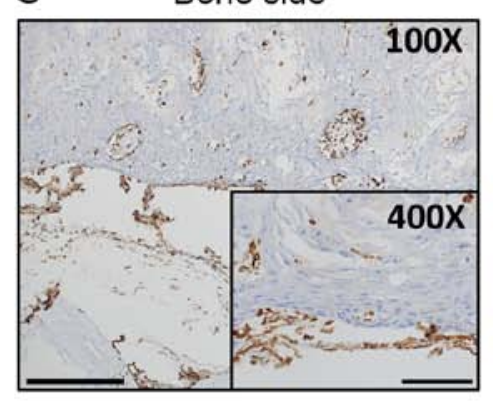

\section{Center side}

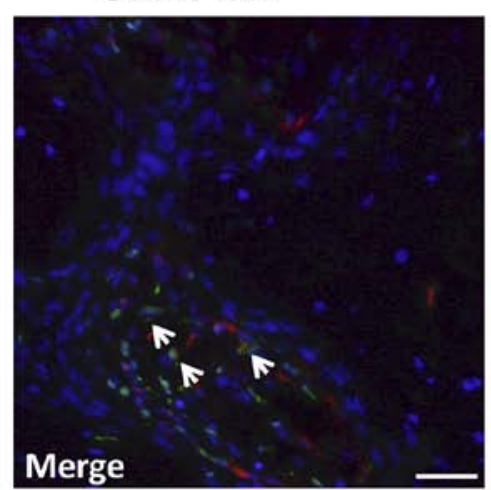

G
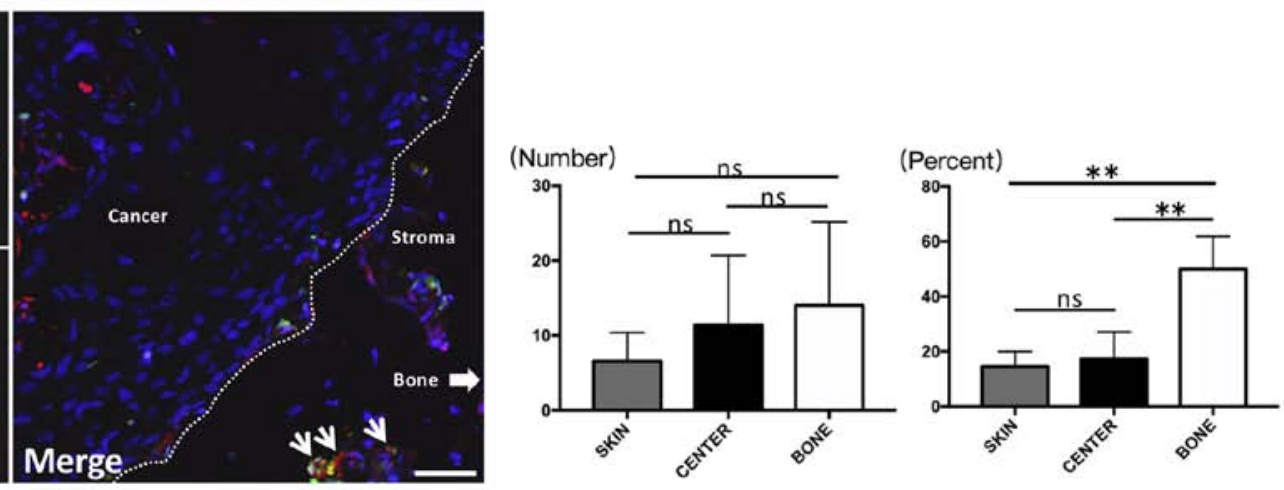

Figure 2. IHC and immunofluorescence of Vimentin. IHC staining for Vimentin was performed on the (A) skin side, (B) center side and (C) bone side. All Vimentin cells were present in the stroma, including on the cancer side. Immunofluorescence double staining for Vimentin and GFP was subsequently performed. Double-positive cells that were spindle or round-shaped were exhibited in sections from the (D) skin side, (E) center side and (F) bone side. (G) The number of Vimentin-positive cells (left) and the percent of double-positive cells (right). No significant differences in the number of Vimentin-positive cells among the three areas were observed. However, the percent of double-positive cells in the bone side was significantly higher compared with the skin side and center side and the average percent of the three areas was $27 \%$. Thin arrows presented in (D-F) indicate Vimentin (+) and GFP (+) double positive staining. The thick arrow in (F) indicate the area of the bone side. Large scale bars in (A-C), $200 \mu \mathrm{m}$ (magnification, x100); smaller scale bars in (A-C), $100 \mu \mathrm{m}$ (magnification, $\mathrm{x} 400$ ); Scale bars in (D-F), $100 \mu \mathrm{m}$ (magnification, $\mathrm{x} 200$ ). ${ }^{* *} \mathrm{P}<0.001$ as indicated. IHC, immunohistochemistry; GFP, green fluorescence protein; ns, no significance.

arranged parallel to the front layers of the cancer in the skin side (Fig. 5A) and bone side (Fig. 5C). In the center side, most of the $\alpha$-SMA-positive cells had accumulated around the borders between the cancer parenchyma and stroma, like a layer (Fig. 5B). The large majority of $\alpha$-SMA-positive cells were spindle-shaped cells with long cytoplasmic extensions, and were obviously different from the shape of GFP-positive cells in the three regions.

$\alpha$-SMA double-fluorescent staining. Almost no GFP-positive cells were also $\alpha$-SMA positive, both in the skin side (Fig. 5D) and center side (Fig. 5E). In the bone side, however, a few
$\alpha$-SMA(+)GFP(+) cells were detected (Fig. 5F) and had a round shape (Fig. 5G).

\section{Discussion}

Our experiments showed that GFP-labeled BMDCs were abundant in the cancer stroma of OSCC. Also, we evaluated the distribution of various cellular constituents and morphological evidence for multilineage differentiation derived from transplanted BMDCs within the TME of OSCC using a BMT mouse model. The cancer stroma can be obviously detected with Vimentin because OSCC is an epithelial tumor and Vimentin 
A

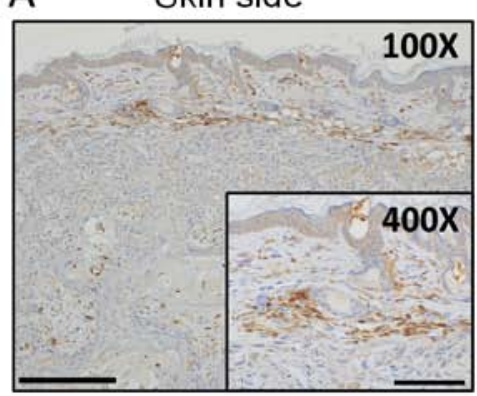

B

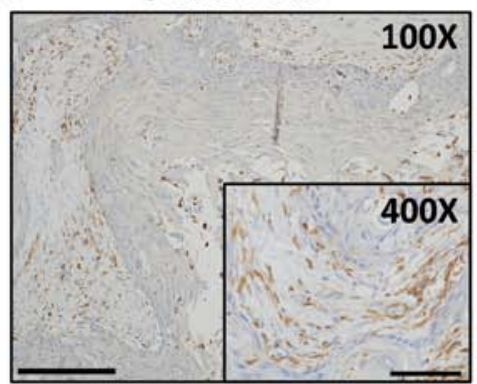

D

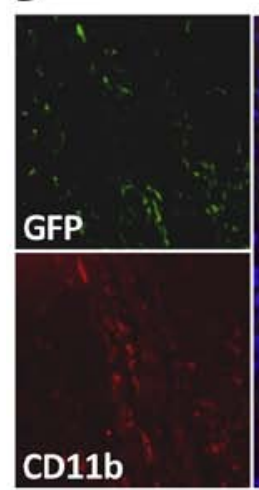

Skin side

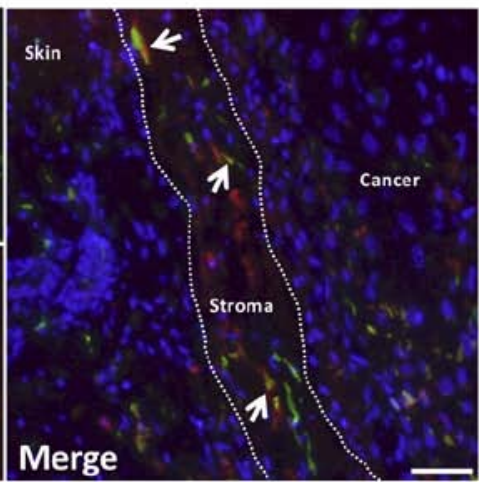

E

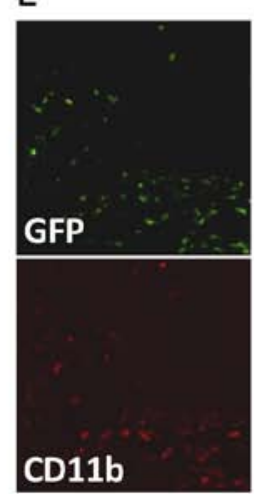

C Bone side

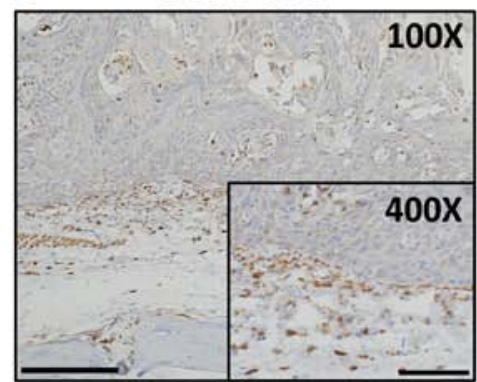

Center side

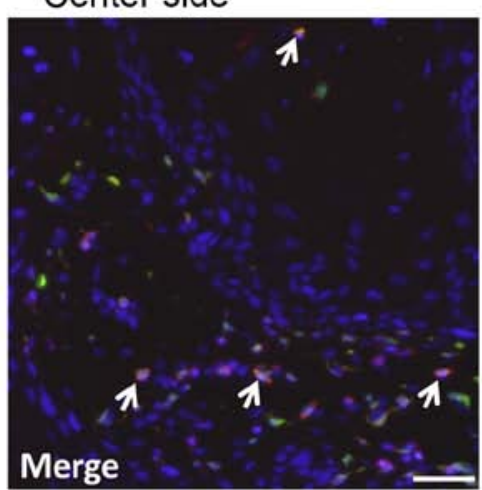

$\mathrm{F}$

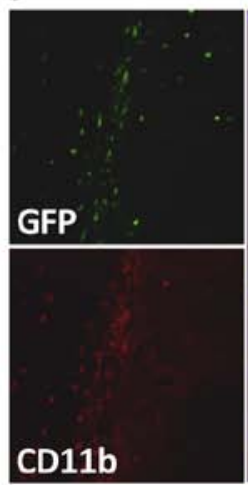

Bone side

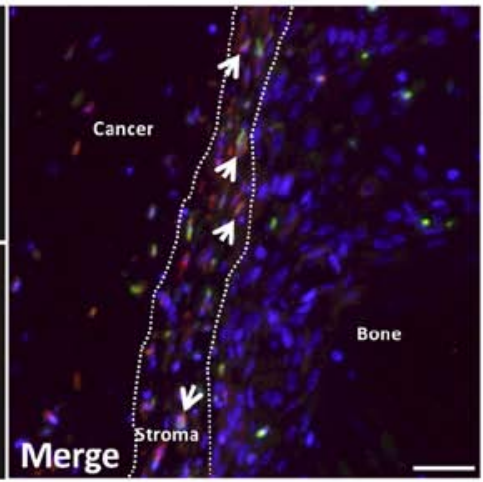

G

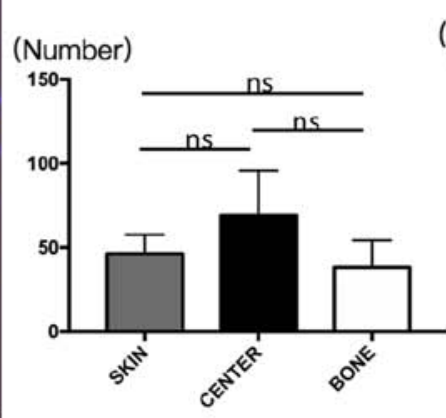

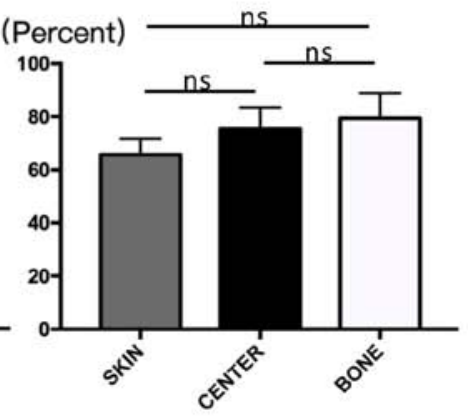

Figure 3. IHC and immunofluorescence of CD11b. IHC features of CD11b. Round or spindle-shaped CD11b cells are observed in (A) the skin side, (B) center side and (C) bone side. Immunofluorescence double staining with CD11b and GFP was subsequently performed. Merged cells are mostly spindle-shaped in (D) the skin side and (F) bone side, whereas round-shaped double-positive cells are observed in (E) the center side. (G) The number of CD11b-positive cells (left) and the percent of double-positive cells (right) are presented. No significant differences were identified. Thin arrows in (D-F) represent CD11b (+) GFP (+) double positive staining. Larger scale bars in (A-C), $200 \mu \mathrm{m}$ (magnification, x100); smaller scale bars in (A-C), 100 $\mu \mathrm{m}$ (magnification, $\mathrm{x} 400$ ). IHC, immunohistochemistry; GFP, green fluorescence protein; ns, no significance.

is a popular marker of mesenchymal cells. Thus, our results confirmed that the majority of stromal cells were Vimentin positive in the cancer stroma. Interestingly, Vimentin-positive cells tended to increase in the order of the skin side, center side, and bone side. Recently, close associations between Vimentin and cancer development and progression as well as chemosensitivity were suggested by various gene profiling studies (33-35). Also, Vimentin expression in colorectal cancer stroma is correlated with shorter survival of patients (36). Double immunofluorescent staining showed that the percent of Vimentin(+)GFP(+) cells was about $27 \%$, indicating that many BMDCs became incorporated into the cancer stroma and may play potential roles in tumorigenesis. Additionally, the percent of Vimentin/GFP double-positive cells in the bone side, which is the front layer of the bone invasion area, was significantly the highest among the three areas of the tumor. The stroma of OSCC contained approximately 50\% GFP-positive cells (BMDCs) in the bone side (Fig. 2G, right). Compared with the other two sides of the tumor, more GFP-positive cells had accumulated in the tumor center, mostly within tumor stromal cells; these cells were rounder and larger. Abundant GFP-labeled BMDCs were previously described in gastric and colon cancer stroma $(37,38)$. Udagawa et al showed that the rate of recruitment of BMDCs varies among different cancer types (39). Lung carcinoma is composed of 30-40\% non-tumor cells recruited from bone marrow. In contrast, the same study showed that the recruitment was lower in a model of osteosarcoma. Thus, our results indicated that BMDCs may 

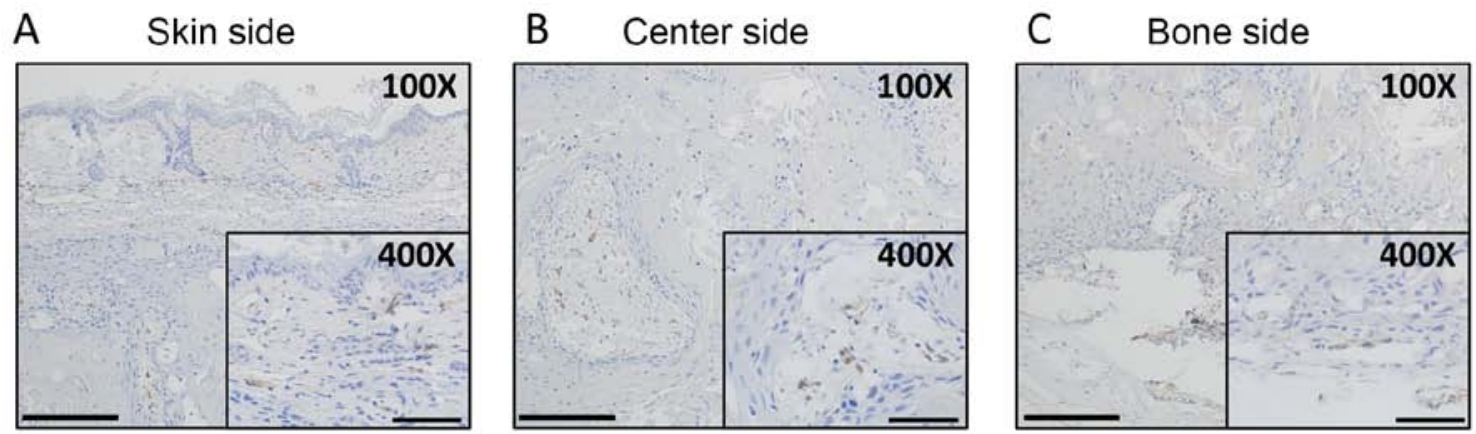

D

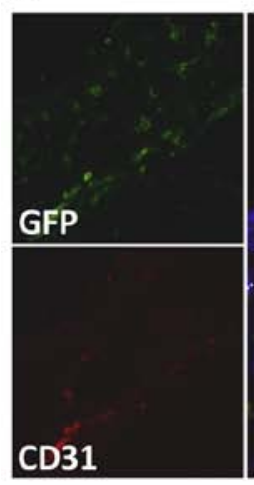

Skin side

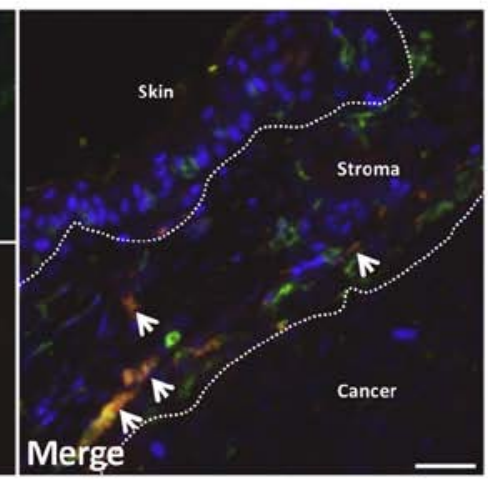

E

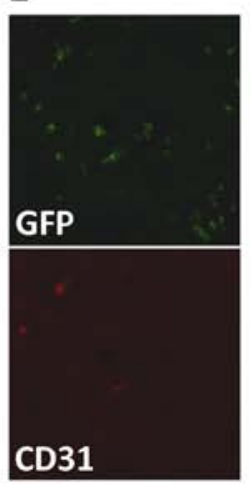

Center side

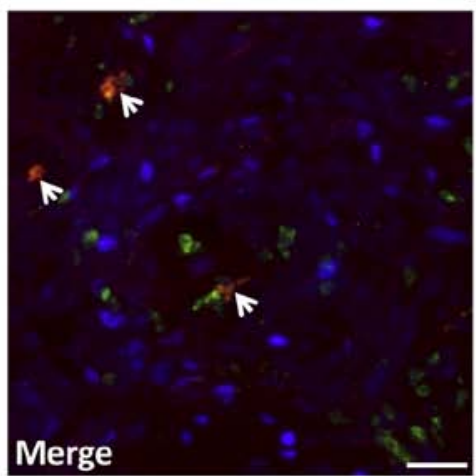

F

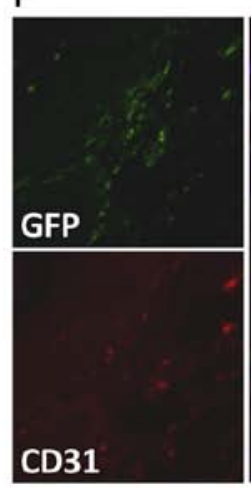

Bone side

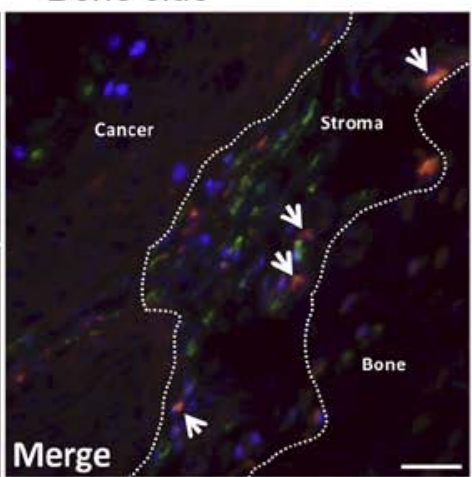

G
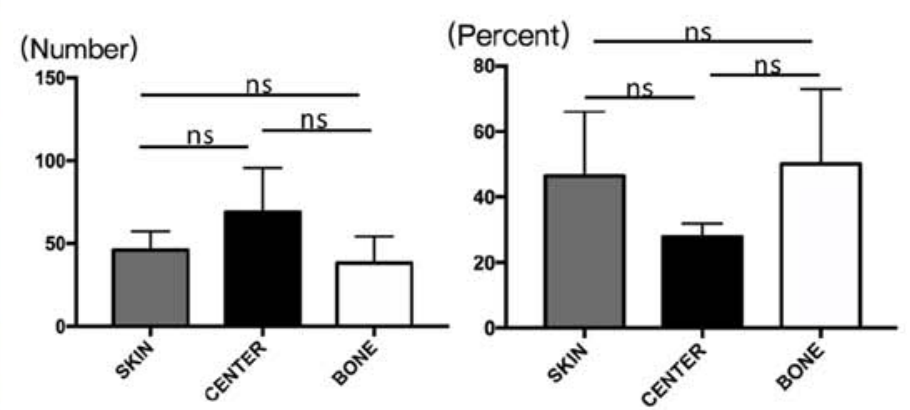

Figure 4. IHC and immunofluorescence of CD31. IHC features of CD31 are presented. Most of the CD31 cells are observed along the front layers of the tumor in (A) the skin side and (C) the bone side, whereas CD31 cells are distributed in the center of the stroma in (B) the center side. The majority of the positive cells were similar to lacunae vasorums. The lumens in the center side appeared larger than those in the skin and bone sides. Immunofluorescence double staining with CD31 and GFP was subsequently performed. Double-positive cells are spindle-shaped or rounded cells were observed in the (D) skin side, (E) center side and $(\mathrm{F})$ bone side. $(\mathrm{G})$ The number of CD31-positive cells (left) and the percent of double-positive cells (right) are presented. No significant differences were identified. Thin arrows in (D-F) represent CD31 (+) and GFP (+) double positive staining. Larger scale bars in (A-C), 200 $\mu \mathrm{m}$ (magnification, x100); smaller scale bars in (A-C) , $100 \mu \mathrm{m}$ (magnification, x400); scale bars in (D-F), $100 \mu \mathrm{m}$ (magnification, x200). IHC, immunohistochemistry; GFP, green fluorescence protein; ns, no significance.

participate in cancer progression and development, especially the process of cancer invasion, because BMDCs infiltrated into the invasive front of the tumor. Furthermore, BMDCs were recruited by the OSCC in the same proportion compared with other types of cancer (Fig. 2G, right). In addition to GFP-positive cells, we traced other important cell types in the cancer stroma. Their characteristics and potential roles are discussed further below.

CD11b is generally known as a marker of monocytes, macrophages, and TAMs (40). TAMs are involved in tumor growth and metastasis (41). In our results, CD11b-positive cells were round or spherical-shaped near the necrotic areas in the center side of the cancer, and more than half of CD11b-positive cells were GFP positive (Fig. 3G, right). Thus, these CD11b(+) $\mathrm{GFP}(+)$ cells were thought to be macrophages that function to phagocytize necrotic tissues. On the other hand, CD11b-positive cells that contacted the cancer parenchyma in the skin side and bone side were spindle-shaped cells that were situated parallel with each other and were scattered along the front layers; more than half of these cells were GFP positive (Fig. 3G, right). Considering the characteristics of their distribution and shape, CD11b-positive cells in the skin and bone side may represent TAMs. Our results indicated that CD11b-positive cells may engulf necrotic tissue in the center area of the cancer and participate in cancer invasion around the peripheral areas of the cancer, especially in the bone side. 
A Skin side

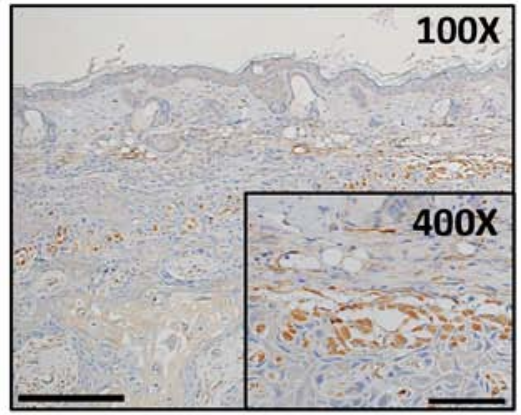

B

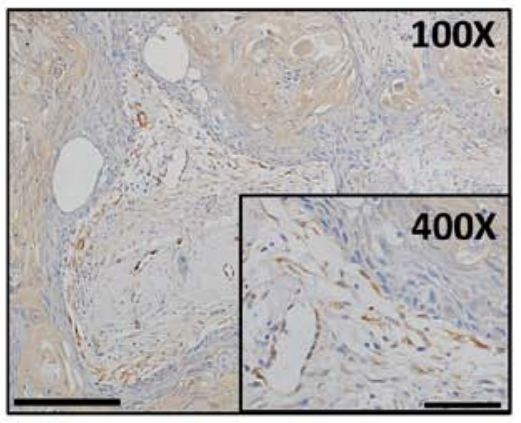

D
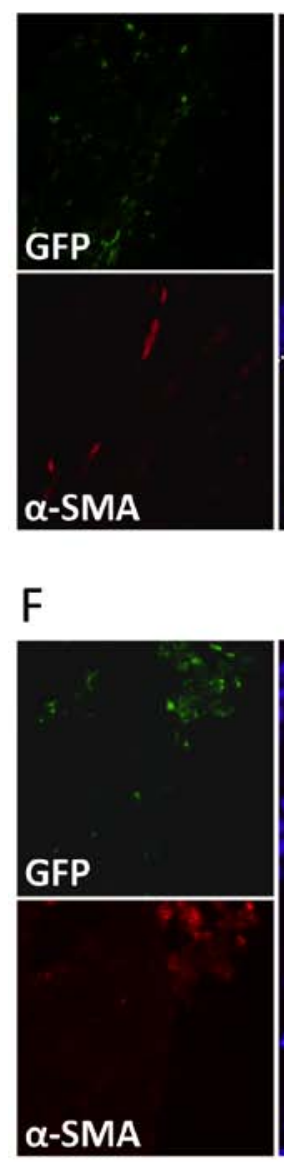

Skin side

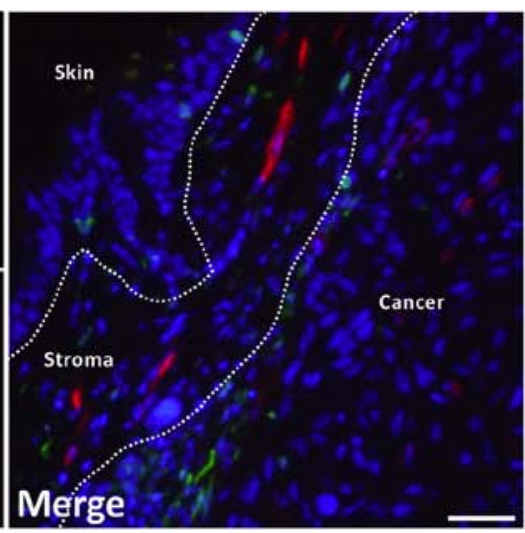

Bone side

E

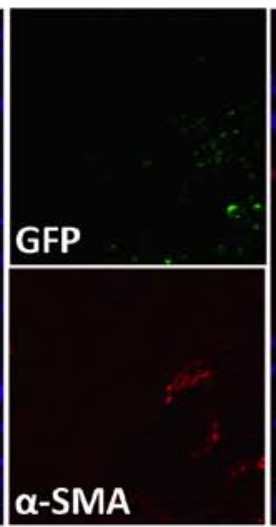

G
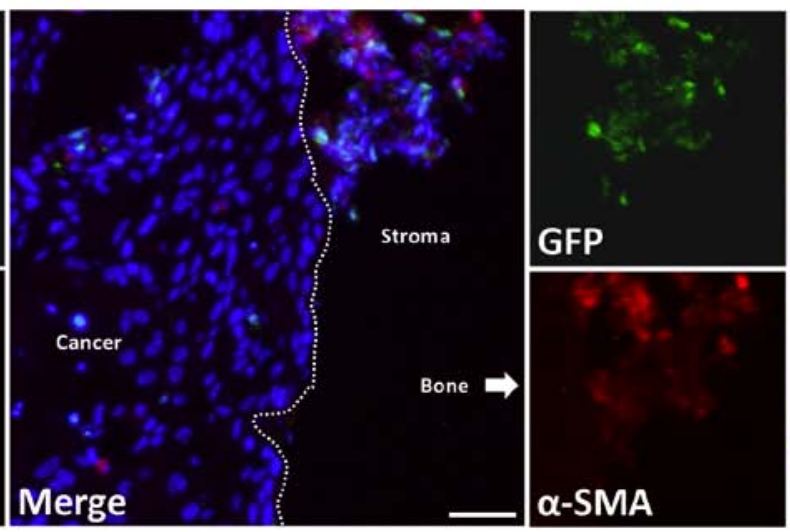

C Bone side

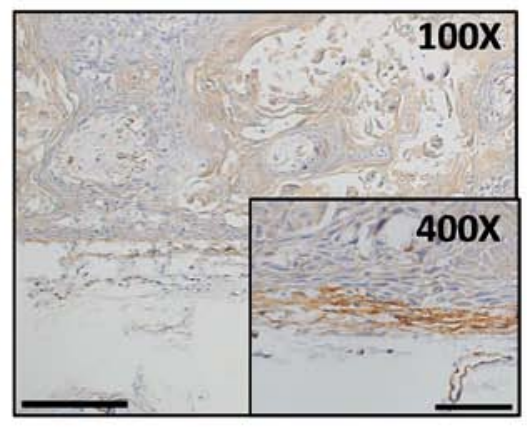

Center side

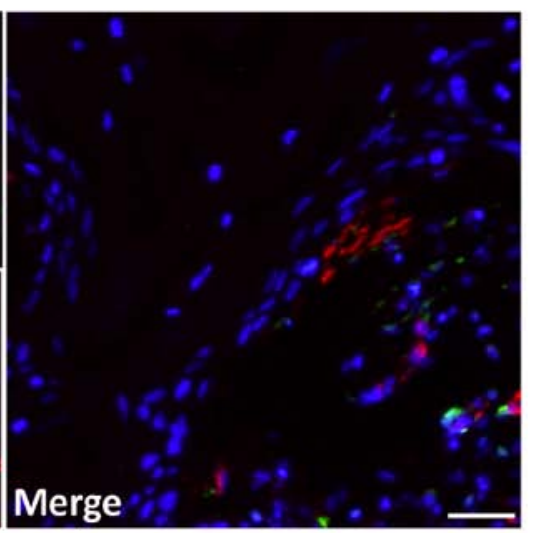

Figure 5. IHC and immunofluorescence of $\alpha$-SMA. IHC features of $\alpha$-SMA are presented. Positive cells were scattered in different areas within (A) the skin side and (C) the bone side, but were parallel the front-most layers. $\alpha$-SMA-positive cells accumulated around the cancer parenchyma in (B) the center side. Immunofluorescence double staining with $\alpha$-SMA and GFP was subsequently performed. Almost no double-positive cells were observed in (D) the skin side (square: Skin area; triangle: Stromal area; Asterisk: Tumor area) and (E) the center side. However, a few double-positive cells in (F) the bone side were observed. The area of double-positive cells is magnified in (G). Thin arrows in (F) represent $\alpha-S M A(+)$ and GFP (+) double positive staining. Thick arrow in (F) represents the area of the bone side. Larger scale bars in (A-C), $200 \mu \mathrm{m}$ (magnification, $\mathrm{x} 100)$; smaller scale bars in (A-C), 100 $\mu \mathrm{m}$ (magnification, $\mathrm{x} 400$ ); scale bars in (D-F; F right image), $100 \mu \mathrm{m}$ (magnification, x200); scale bar in (F; left image), $100 \mu \mathrm{m}$ (magnification, x400). IHC, immunohistochemistry; SMA, smooth muscle actin; GFP, green fluorescence protein.

Therefore, BMDCs likely play a crucial role, especially at the periphery of the cancer, as TAMs.

Angiogenesis of tumors has critical impacts on development of the tumor. The details of the contribution of BMDCs to tumor angiogenesis are still unknown. However, bone marrow-derived endothelial progenitor cells and tissue stem cells have been identified (42). Moreover, recent studies have provided increasing evidence that postnatal neovascularization does not rely exclusively on sprouting of preexisting vessels, but also involves bone marrow-derived circulating endothelial precursors (43). In our study, about half of the CD31-positive cells were derived from bone marrow in the cancer stroma, and the number of CD31-positive cells tended to be higher in the peripheral areas of the cancer compared to the center side. However, the opposite trend was observed for CD31(+)GFP(+) cells. Mature blood vessels with larger lumens and thicker walls were found in the center side, providing compulsory nutrition for tumorigenesis, compared with the 
peripheral sides of the cancer. Therefore, BMDCs are involved in tumor angiogenesis, and especially CD31(+)GFP(+) cells may participate in tumor angiogenesis in invasive areas owing to the higher quantity of BMDCs in tumor peripheral areas.

$\alpha$-SMA is a popular marker of myoepithelial cells and CAFs in tumors. We found many spindle-shaped $\alpha$-SMA-positive cells surrounding the cancer parenchyma. However, almost no $\alpha-\operatorname{SMA}(+) \operatorname{GFP}(+)$ cells were seen. Therefore, in cancer stroma, $\alpha$-SMA-positive cells are derived from recipient tissue. Several studies have explored the origins of CAFs, including resident fibroblasts (44), smooth muscle cells, endothelial cells, epithelial cells (through epithelial-mesenchymal transition), fibrocytes, and BMDCs such as mesenchymal stem cells $(45,46)$. Moreover, another study discovered that BMDCs may change to cancer-associated orthotopic myofibroblasts by the education of gastric cells (37). Another study indicated that about $20 \%$ of local CAFs were derived from mesenchymal stem cells present in the bone marrow using a gastric inflammatory carcinogenesis model (47). However, the methods of these reports were different from our study method. In the previous studies, only mesenchymal stem cells (MSCs) or adhesive cells of bone marrow were transplanted, on the other hand, in our study we transplanted all bone marrow cells. In previous studies, MSCs of bone marrow differentiated into CAFs. However, the bone marrow includes hematopoietic stem cells, mesenchymal stem cells, and somatic pluripotent progenitor cells, and mesenchymal stem cells only comprise $0.001-0.01 \%$ of cells in the bone marrow and mesenchymal stem cells content is very low (48). Thus, it is possible that mesenchymal stem cells failed to engraft following bone marrow transplantation in this study, but our methods mimicked in vivo condition. In terms of tumor stroma, there are almost two orientations, generally. One of origins is bone marrow, the other is host tissues around tumor. In our study, in oral squamous cell carcinoma, these $\alpha$-SMA(+) CAFs might originate mostly from host tissues rather than BMDCs. Therefore, our results showed that unlike these studies, in OSCC, CAFs originate mostly from the host tissue rather than BMDCs. We discovered very few $\alpha-\operatorname{SMA}(+) \mathrm{GFP}(+)$ cells in the bone side after amplification. However, these cells may not be CAFs because the morphology of these cells was round, which distinguished them from CAFs. Our experiments indicated that GFP-positive BMDCs may play an important role in inducing CAFs because these GFP-positive cells were distributed side by side with $\alpha$-SMA-positive cells.

In conclusion, given all the findings we observed from the GFP mouse BMT model, BMDCs may participate in the processes of tumorigenesis and cancer development. The different distributions and morphological characteristics provide authentic evidence for the involvement of BMDCs in the development of cancer via differentiation into various kinds of cells in the cancer stroma, such as macrophages, fibroblasts, angioblasts, etc. Our results suggest roles for these cells in tumorigenesis due to their multilineage differentiation potential.

\section{Acknowledgements}

Not applicable.

\section{Funding}

The presen study was funded by Japanese Society for Promotion of Science KAKENHI Grant-in-Aid for Scientific Research (grant nos. 18K09789, 18K17224, 16K20577 and 19K19160).

\section{Availability of data and materials}

The datasets used and/or analyzed during the present study are available from the corresponding author on reasonable request.

\section{Authors' contributions}

CA and KT designed the experiments. HK, SY, MWO and HO performed immunohistochemistry. MF and SS performed statistical analysis. KN, HT, ZJN and HN collected the data and drafted the manuscript. All authors approved the final manuscript.

\section{Ethics approval and consent to participate}

All animal experiments were performed in accordance with relevant guidelines and regulations, and were approved by the institutional Committees of Okayama University (approval no. OKU-2017406).

\section{Patient consent for publication}

Not applicable.

\section{Competing interests}

The authors declare that they have no competing interests.

\section{References}

1. Joyce JA and Pollard JW: Microenvironmental regulation of metastasis. Nat Rev Cancer 9: 239-252, 2009.

2. Yashiro $M$ and Hirakawa $\mathrm{K}$ : Cancer-stromal interactions in scirrhous gastric carcinoma. Cancer Microenviron 3: 127-135, 2010.

3. Fuyuhiro Y, Yashiro M, Noda S, Matsuoka J, Hasegawa T, Kato Y, Sawada T and Hirakawa K: Cancer-associated orthotopic myofibroblasts stimulates the motility of gastric carcinoma cells. Cancer Sci 103: 797-805, 2012.

4. Tripathi M, Billet S and Bhowmick NA: Understanding the role of stromal fibroblasts in cancer progression. Cell Adhes Migr 6: 231-235, 2012.

5. Harper J and Sainson RC: Regulation of the anti-tumour immune response by cancer-associated fibroblasts. Semin Cancer Biol 25: 69-77, 2014

6. Li H, Fan X and Houghton JM: Tumor microenvironment: The role of the tumor stroma in cancer. J Cell Biochem 101: 805-815, 2007.

7. Clark RAF (Ed): The molecular cell biology of wound repair. Plenum Press New York 3: 50, 1996.

8. Desmoulière A, Geinoz A, GabbianiFand Gabbiani G: Transforming growth factor-beta 1 induces alpha-smooth muscle actin expression in granulation tissue myofibroblasts and in quiescent and growing cultured fibroblasts. J Cell Biol 122: 103-111, 1993.

9. Roberts AB, Sporn MB, Assoian RK, Smith JM, Roche NS Wakefield LM, Heine UI, Liotta LA, Falanga V, Kehrl JH, et al: Transforming growth factor type beta: Rapid induction of fibrosis and angiogenesis in vivo and stimulation of collagen formation in vitro. Proc Natl Acad Sci USA 83: 4167-4171, 1986.

10. Tjomsland V: Studies of the tumor microenvironment: Local and systemic effects exerted by the cross-talk between tumor and stroma cells in pancreatic cancer. PhD dissertation. Linköping University. Publication no. 1219. Linköping, Sweden, 2010. 
11. Bhowmick NA, Neilson EG and Moses HL: Stromal fibroblasts in cancer initiation and progression. Nature 432: 332-337, 2004.

12. De Wever O and Mareel M: Role of tissue stroma in cancer cell invasion. J Pathol 200: 429-447, 2003.

13. Kalluri R and Zeisberg M: Fibroblasts in cancer. Nat Rev Cancer 6: 392-401, 2006.

14. Micke P and Ostman A: Exploring the tumour environment Cancer-associated fibroblasts as targets in cancer therapy. Expert Opin Ther Targets 9: 1217-1233, 2005.

15. Bhowmick NA, Chytil A, Plieth D, Gorska AE, Dumont N, Shappell S, Washington MK, Neilson EG and Moses HL: TGF-beta signaling in fibroblasts modulates the oncogenic potential of adjacent epithelia. Science 303: 848-851, 2004

16. Mbeunkui $\mathrm{F}$ and Johann DJ Jr: Cancer and the tumor microenvironment: A review of an essential relationship. Cancer Chemother Pharmacol 63: 571-582, 2009.

17. Costea DE, Hills A, Osman AH, Thurlow J, Kalna G, Huang X, Pena Murillo C, Parajuli H, Suliman S, Kulasekara KK, et al: Identification of two distinct carcinoma-associated fibroblast subtypes with differential tumor-promoting abilities in oral squamous cell carcinoma. Cancer Res 73: 3888-3901, 2013.

18. Routray S, Sunkavali A and Bari KA: Carcinoma-associated fibroblasts, its implication in head and neck squamous cell carcinoma: A mini review. Oral Dis 20: 246-253, 2014.

19. Kessenbrock K, Plaks V and Werb Z: Matrix metalloproteinases: Regulators of the tumor microenvironment. Cell 141: 52-67, 2010.

20. Naritani $M$, Inoue $M$, Raju R, Miyagi $M$, Oshima $M$ and Matsuka Y: Analysis of Bone marrow-derived mesenchymal stem cell kinetics after short-term stimulation with tumor necrosis factor- $\alpha$ (TNF- $\alpha$ ). J Hard Tissue Biol 28: 99-108, 2019.

21. Badiavas EV, Abedi M, Butmarc J, Falanga V and Quesenberry P: Participation of bone marrow derived cells in cutaneous wound healing. J Cell Physiol 196: 245-250, 2003.

22. Houghton J, Stoicov C, Nomura S, Rogers AB, Carlson J, Li H, Cai X, Fox JG, Goldenring JR and Wang TC: Gastric cancer originating from bone marrow-derived cells. Science 306: $1568-1571,2004$

23. Pittenger MF, Mackay AM, Beck SC, Jaiswal RK, Douglas R, Mosca JD, Moorman MA, Simonetti DW, Craig S and Marshak DR: Multilineage potential of adult human mesenchymal stem cells. Science 284: 143-147, 1999.

24. Caplan AI: Mesenchymal stem cells. J Orthop Res 9: 641-650, 1991.

25. Krause DS, Theise ND, Collector MI, Henegariu O, Hwang S, Gardner R, Neutzel S and Sharkis SJ: Multi-organ, multi-lineage engraftment by a single bone marrow-derived stem cell. Cell 105: 369-377, 2001

26. Tsujigiwa H, Nishizaki K, Teshima T, Takeda Y, Yoshinobu J, Takeuchi A, Orita Y, Sugata Y, Nagatsuka H and Nagai N: The engraftment of transplanted bone marrow-derived cells into the olfactory epithelium. Brain Res 1052: 10-15, 2005.

27. Aghi M and Chiocca EA: Contribution of bone marrow-derived cells to blood vessels in ischemic tissues and tumors. Mol Ther 12: 994-1005, 2005.

28. Lyden D, Hattori K, Dias S, Costa C, Blaikie P, Butros L, Chadburn A, Heissig B, Marks W, Witte L, et al: Impaired recruitment of bone-marrow-derived endothelial and hematopoietic precursor cells blocks tumor angiogenesis and growth Nat Med 7: 1194-1201, 2001

29. Bamba S, Lee CY, Brittan M, Preston SL, Direkze NC, Poulsom R, Alison MR, Wright NA and Otto WR: Bone marrow transplantation ameliorates pathology in interleukin-10 knockout colitic mice. J Pathol 209: 265-273, 2006

30. Kawai H, Tsujigiwa H, Siar CH, Nakano K, Takabatake K, Fujii M, Hamada M, Tamamura R and Nagatsuka H: Characterization and potential roles of bone marrow-derived stromal cells in cancer development and metastasis. Int J Med Sci 15: 1406-1414, 2018.

31. Masui M, Okui T, Shimo T, Takabatake K, Fukazawa T, Matsumoto K, Kurio N, Ibaragi S, Naomoto Y, Nagatsuka H and Sasaki A: Novel midkine inhibitor iMDK inhibits tumor growth and angiogenesis in oral squamous cell carcinoma. Anticancer Res 36: 2775-2781, 2016.

32. Mhawech-Fauceglia P, Wang D, Samrao D, Kim G, Lawrenson K, Meneses T, Liu S, Yessaian A and Pejovic T: Clinical implications of marker expression of carcinoma-associated fibroblasts (CAFs) in patients with epithelial ovarian carcinoma after treatment with neoadjuvant chemotherapy. Cancer Microenviron 7: 33-39, 2014
33. Zajchowski DA, Bartholdi MF, Gong Y, Webster L, Liu HL, Munishkin A, Beauheim C, Harvey S, Ethier SP and Johnson PH: Identification of gene expression profiles that predict the aggressive behavior of breast cancer cells. Cancer Res 61: 5168-5178, 2001.

34. Mellick AS, Day CJ, Weinstein SR, Griffiths LR and Morrison NA: Differential gene expression in breast cancer cell lines and stroma-tumor differences in microdissected breast cancer biopsies revealed by display array analysis. Int J Cancer 100: 172-180, 2002

35. Peñuelas S, Noé V and Ciudad CJ: Modulation of IMPDH2, survivin, topoisomerase I and vimentin increases sensitivity to methotrexate in HT29 human colon cancer cells. FEBS J 272: 696-710, 2005

36. Ngan CY, Yamamoto H, Seshimo I, Tsujino T, Man-i M, Ikeda JI, Konishi K, Takemasa I, Ikeda M, Sekimoto M, et al: Quantitative evaluation of vimentin expression in tumour stroma of colorectal cancer. Br J Cancer 96: 986-992, 2007.

37. Kasashima H, Yashiro M, Nakamae H, Masuda G, Kinoshita H, Morisaki T,Fukuoka T, Hasegawa T, Sakurai K, Toyokawa T, et al: Bone marrow-derived stromal cells are associated with gastric cancer progression. Br J Cancer 113: 443-452, 2015.

38. Ishii S, Tsuji S, Tsujii M, Kanazawa Y, Nishida T, Iijima H, Yasumaru M, Irie T, Yamamoto K, Tsutsui S, et al: Involvement of bone marrow-derived stromal cells in gastrointestinal cancer development and metastasis. J Gastroenterol Hepatol 23 (Suppl 2): S242-S249, 2008.

39. Udagawa T, Puder M, Wood M, Schaefer BC and D'Amato RJ: Analysis of tumor-associated stromal cells using SCID GFP transgenic mice: Contribution of local and bone marrow-derived host cells. FASEB J 20: 95-102, 2006

40. Colegio OR, Chu NQ, Szabo AL, Chu T, Rhebergen AM, Jairam V, Cyrus N, Brokowski CE, Eisenbarth SC, Phillips GM, et al: Functional polarization of tumour-associated macrophages by tumour-derived lactic acid. Nature 513: 559-563, 2014.

41. Komohara Y, Jinushi M and Takeya M: Clinical significance of macrophage heterogeneity in human malignant tumors. Cancer Sci 105: 1-8, 2014.

42. Asahara T, Murohara T, Sullivan A, Silver M, van der Zee R, Li T, Witzenbichler B, Schatteman G and Isner JM: Isolation of putative progenitor endothelial cells for angiogenesis. Science 275: 964-967, 1997.

43. Le Ricousse-Roussanne LS, Barateau V, Contreres JO, Boval B, Kraus-Berthier L and Tobelem G: Ex vivo differentiated endothelial and smooth muscle cells from human cord blood progenitors home to the angiogenic tumor vasculature. Cardiovasc Res 62: 176-184, 2004.

44. Orimo A, Gupta PB, Sgroi DC, Arenzana-SeisdedosF, Delaunay T, Naeem R, Carey VJ, Richardson AL and Weinberg RA: Stromal fibroblasts present in invasive human breast carcinomas promote tumor growth and angiogenesis through elevated SDF-1/CXCL12 secretion. Cell 121: 335-348, 2005.

45. Direkze NC, Forbes SJ, Brittan M, Hunt T, Jeffery R, Preston SL, Poulsom R, Hodivala-Dilke K, Alison MR and Wright NA: Multiple organ engraftment by bone-marrow-derived myofibroblasts and fibroblasts in bone-marrow-transplanted mice. Stem Cells 21: 514-520, 2003.

46. Karnoub AE, Dash AB, Vo AP, Sullivan A, Brooks MW, Bell GW, Richardson AL, Polyak K, Tubo R and Weinberg RA: Mesenchymal stem cells within tumour stroma promote breast cancer metastasis. Nature 449: 557-563, 2007.

47. Quante M, Tu SP, Tomita H, GondaT, Wang SS, Takashi S, Baik GH, Shibata W, Diprete B, Betz KS, et al: Bone marrow-derived myofibroblasts contribute to the mesenchymal stem cell niche and promote tumor growth. Cancer Cell 19: 257-272, 2011.

48. Ohgushi $\mathrm{H}$ and Caplan AI: Stem cell technology and bioceramics: From cell to gene engineering. J Biomed Mater Res 48: 913-927, 1999.

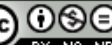

This work is licensed under a Creative Commons Attribution-NonCommercial-NoDerivatives 4.0 International (CC BY-NC-ND 4.0) License. 